\title{
Lofliedere - basisteoretiese elemente uit Efesiërs 1:3-14
}

\author{
Ben de Klerk \\ Skool vir Kerkwetenskappe \\ Potchefstroomse Universiteit vir $\mathrm{CHO}$ \\ POTCHEFSTROOM \\ E-pos: kwsbjdk@puknet.puk.ac.za
}

\begin{abstract}
Songs of praise - Basis-theoretical elements from Ephesians 1:3-14

The singing of new songs of praise is frequently introduced into the worship service without evaluating the contents of the songs properly. In this article Ephesians 1:3-14 is highlighted in an effort to ascertain whether basis-theoretical elements (measures for creating and evaluating) emerge from this pericope, and if they do, what these elements are. The structure and contents of Ephesians 1:1314 are studied to determine what basis-theoretical elements of the song of praise can be inferred from this pericope. Subsequently it is determined in what way the relation between dogma and doxa clarifies the investigation. The praise and worship movement is evaluated and an effort is made to summarize the basis-theoretical elements implied in Ephesians 1:13-14. In creating and evaluating praise songs a well-planned structure is necessary in considering elements like the refrain and the repetition of the most important themes. The praise song should celebrate the beauty of the Triune God and his great deeds. The praise song ought to have its origin in revelation and should interact with dogmatical elements. The praise song still plays an important role in the conservation and growth of the church. The praise song ought to be born from the struggle, pain and triumph of the church and not from motives of sentimentality and rabble-rousing.
\end{abstract}

\section{Inleiding - die unieke plek van lofliedere}

Die meeste groot denominasies in die wêreld het die afgelope vyftien jaar nuwe liedboeke geproduseer wat uitgeloop het op 'n himneontploffing (Bradley, 2000:41). Behalwe die liedboeke het die praise and worship-beweging ontstaan, wat veral fokus op lofliedere. Die praise and 
worship-musiek wat 25 jaar gelede ontstaan het en wat van kitaar- en drommusiek gebruik maak, het gegroei tot 'n multimiljoendollar-industrie wat die gebruik van videos, bandopnames, publikasies en Internet Webdienste insluit. Die sing van nuwe lofliedere is dikwels ingevoer sonder om die inhoud daarvan behoorlik te evalueer, omdat maatstawwe vir die beoordeling daarvan nie behoorlik vasgestel is nie. In hierdie artikel word toegespits op Efesiërs 1:3-14 in 'n poging om te probeer vasstel of, en indien wel, watter basisteoretiese elemente vir die skep en evaluering van lofliedere uit hierdie perikoop na vore kom.

Die himne is nie 'n nuwe verskynsel nie, want by die Jode in die Diaspora was die himnegesang in die sinagoges van besondere betekenis en hierdie Joodse liedere het die grootste invloed op die himnes van die Nuwe Testament gehad (Viljoen, 1990:68). Sang het reeds in die eerste Christelike gemeenskap voorgekom (vgl. Matt. 26:30) en die vreugde wat deur Christus se verlossing teweeggebring is, het onder andere in die sing van lofliedere tot uiting gekom (Hand. 2:46-47; 1 Kor. 14:15b, 26). Die vroeë kerk het Ou-Testamentiese himnes en psalms, veral messiaanse psalms op 'n nuwe wyse gesing. Onder leiding van die Heilige Gees is ook nuwe himnes oor Christus gedig deur die vorm van die Joodse liedere te gebruik (Malan, 1998:512). Die himniese stof is versprei in die verskillende boeke van die Nuwe Testament en in baie gevalle is dit wat voorkom, fragmentaries van aard, byvoorbeeld die lofliedere in Lukas, liedere in die boek Openbaring en spesifieke Christelike himnes (Martin, 1983:132-133).

'n Himne is 'n baie effektiewe onderrigmiddel: 'n lied met aangename woorde, 'n treffende styl en 'n besondere struktuur wat maklik is om te onthou. Die himne is in die eerste plek bedoel as 'n gemeente se aanbidding en lofprysing van God. Deur die himne word bewondering, dankbaarheid, geloof, hoop, liefde, vreugde, en selfs twyfel en pyn voor God uitgestort (Malan, 1998:522). Wainwright (1980:198-199) sê die basiese elemente van die Christelike himne is lof aan God wat besing word, ook belydenis, gebed, toewyding en aanroeping van God (vgl. Barkhuizen, 1989:1-16).

Meer as enige ander Nuwe-Testamentiese brief het Efesiërs die aard en vorm van gebed, veral gekenmerk deur die lofprysing in die gebed. Daar is jubelende lofprysings op God die Vader se liefde, lofprysings op die verkiesing en aanneming tot kinders, op Christus se verlossing en vergewing en die Heilige Gees se krag en verseëling. Hierdie uitgebreide lofprysing vorm die raamwerk vir die belydenis van God se ewige plan en Christus se skepping van 'n nuwe gemeenskap wat uit Jode en heidene bestaan. Efesiërs 1:3-14 kan daarom as meditatiewe lied geklassifiseer word, omdat dit liedere is waarin gejubel word oor hoe Christus in die 
mens se plek die toorn van God gedra het. Juis daarom was Efesiërs Calvyn se groot liefde want, sê hy, die brief beweeg die leser tot bewondering, aanbidding en lofprysing van God (De Klerk, 1988:42). Die brief is nie in die eerste plek bedoel om die Efesiërs dogmatiese kennis by te bring nie, maar om hulle tot aanbidding te lei (Floor, 1995:37).

In hierdie artikel sal die volgende werkplan gevolg word: Eers sal uit die struktuur en inhoud van Efesiërs 1:3-14 nagegaan word of, en indien wel, watter basisteoretiese elemente vir die loflied afgelei kan word; daarna sal gepoog word om kortliks vas te stel watter lig die verhouding dogma en doksa op die ondersoek werp. Ook sal die praise and worshipbeweging kernagtig geëvalueer word en sal 'n poging aangewend word om samevattende basisteoretiese elemente vanuit Efesiërs 1:3-14 te beskryf.

\section{Lofliedere - basisteoretiese elemente uit die struktuur van Efesiërs 1:3-14}

Die bedoeling is nie om in hierdie onderdeel ' $n$ volledige uiteensetting van die struktuur van die perikoop te gee nie, maar om die relevante dele aan te dui om daaruit moontlik basisteoretiese elemente te kan aflei. Dit is vir die verstaan van Efesiërs 1:3-14, sowel as vir die struktuur en boodskap van die brief van kardinale belang dat 1:3-3:21 'n tiperende eie aard vertoon. Hierdie tipering en aard van Efesiërs 1:3-3:21 plaas dié deel van die brief in die genre van 'n bepaalde Joodse gebedsvorm (die berakah) (Roberts 1984:139), alhoewel dit 'n duidelik Christelike inhoud het. Die volgende elemente van die berakah is in die eerste drie hoofstukke van Efesiërs teenwoordig (Roberts, 1983:13, 27):

- 'n uitroep van lof (1:3a)

- redes vir hierdie lof $(1: 3 b-14)$

- voorbidding (1:15-21)

- geloofsbelydenis (1:22-23)

- verduidelikings van die belydenis $(2: 1-10 ; 11-18 ; 19-22)$

- voorbidding met onderbreking (3:1 [2-13]-19)

- lofsegging (3:20-21)

Die Joodse berakah-gebed of -liturgie is 'n bepaalde vorm van lofsang en by hierdie gebede het daar altyd twee elemente voorgekom, naamlik 'n uitroep van lof, gevolg deur die redes waarom God geprys moet word (vgl. Gen. 24:27; Pss. 103-106; 111; 117-118; 135-136; 138; 144-145; 148-150; Roberts, 1983:29; Viljoen, 1990:120). Die rede waarom God 
geprys moet word, word in Efesiërs 1 deur twee chiastiese gedagtes uitgedruk, naamlik "ons" (1:3c) en die "geestelike seëninge" (1:3d). Die tweede gedagte (geestelike seëninge) word in 1:4-10 uitgebou en die eerste (ons) in 1:11-14. Terwyl 1:4-6 oor goddelike uitverkiesing gaan, fokus 1:7-10 op ons verlossing. Ons goddelike uitverkiesing loop uit op verlossing. Terwyl 1:11-12 handel oor Joodse Christene, gaan dit in 1:13-14 oor Christene uit die heidene. Die objek van die verlossing brei uit van Joodse Christene na Christene uit die heidene (Bhae, 2000:64). Die geheel word weer met 'n doksologie afgesluit, in welke geval die elemente van laasgenoemde dan gewoonlik chiasties teenoor die eerste lofroep gerangskik was (vgl. De Klerk, 1988:43). Die $\epsilon \cup \lambda \circ \gamma \in T O \hat{~ l e i ~ d i e ~}$ berakah-styl van die perikoop in (vgl. ook Bhae, 2000:51). Die inleidende byvoeglike naamwoord $\epsilon \cup \lambda \circ \gamma \in T O$, wat as 'n lofroep gebruik word, is 'n unieke doksologiese formule wat in die Nuwe Testament slegs ten opsigte van lofprysing teenoor God gebruik word (vgl. Rom. 1:25; 9:5; 2 Kor. 1:3; 11:31; Mark. 14:61; Luk. 1:68; 1 Pet. 1:3). Dit is 'n uitdrukking van matelose verwondering, danksegging, lofprysing en aanbidding teenoor God, spesifiek vir wat Hy in Christus gedoen het (Mouton, 1987:126).

Uitstaande kenmerke in die perikoop is die volgende: Dit is duidelik dat die begrip $\in \nu$ X $\rho \iota \tau \uparrow \hat{A}$ regdeur die perikoop sentraal staan, en as sodanig die belangrikste rigtingwyser met betrekking tot die hooftema of boodskap van die perikoop uitmaak (Mouton, 1987:84; vgl. Barkhuizen, 1990:401-409). Ook die uitdrukkings in vers 5, 9 en 11 oor die wil van God is kenmerkende herhalings, amper iets van 'n refrein. Die doel van die hoofhandeling word op veelseggende wyse in elke onderdeel met $\epsilon \hat{i}$ aangedui (verse $6,10,12,14$ ). Hierdie doelstellings kom dus in 'n parallelistiese struktuur tot mekaar voor, en voorsien die perikoop van 'n besondere linguistiese balans. Daar is verder 'n hoë frekwensie van die voorsetsels $\epsilon \nu$, KaTa en $\epsilon \hat{i}$ (Mouton, 1987:85). Copes (1996:21) toon aan dat die herhaling van die frase "tot lof van sy heerlikheid" en die inhoud van die hele perikoop 'n struktuur suggereer wat tegelyk chronologies en trinitaries is. Vers 3-6 dui aan die genadige bedoeling van God die Vader (verlede), verse 7-12 die verlossingswerk van Christus die Seun (die hede) en verse 13-14 die beloofde erfdeel deur die Heilige Gees (die toekoms).

In die aanduiding van die breë struktuur van die perikoop word Mouton (1987:81 e.v.) gevolg. Die struktuur kan in terme van God se handelinge, metodes en doelwitte voorgestel word: 


\begin{tabular}{|c|c|c|}
\hline $\begin{array}{l}\text { God se handeling of } \\
\text { seëning }\end{array}$ & God se metode & God se doel \\
\hline Uitverkiesing & $\begin{array}{l}\text { Vers 5: "deur Jesus } \\
\text { Christus" }\end{array}$ & $\begin{array}{l}\text { "Om heilig ..." (vers 4) } \\
\text { "Tot lof van die heer- } \\
\text { likheid van sy genade" } \\
\text { (vers 6) }\end{array}$ \\
\hline Verlossing & $\begin{array}{l}\text { "In Hom" (vers } 7 \text { ) } \\
\text { "Deurdat Hy ons sy wil } \\
\text { bekend gemaak het" } \\
\text { (vers 9) }\end{array}$ & $\begin{array}{l}\text { "Met die doel om alle } \\
\text { dinge ... onder een hoof } \\
\text { in Christus te verenig" } \\
\text { (vers 10) }\end{array}$ \\
\hline Erflating & $\begin{array}{l}\text { "In Hom in wie ons ook } \\
\text { 'n erfdeel ontvang het" } \\
\text { (vers 11) }\end{array}$ & $\begin{array}{l}\text { "sodat ons kan wees tot } \\
\text { lof van sy heerlikheid" } \\
\text { (vers 12) }\end{array}$ \\
\hline Verseëling & $\begin{array}{l}\text { "In wie julle ... verseël is } \\
\text { met die Heilige Gees" } \\
\text { (vers 13) }\end{array}$ & $\begin{array}{l}\text { "Tot lof van sy heerlik- } \\
\text { heid" (vers 14) }\end{array}$ \\
\hline
\end{tabular}

(Mouton, 1987:82).

Die perikoop se fyn gestruktureerdheid blyk verder in terme van God se motivering en tydsbepaling en hierdie waarneming onderstreep nogeens die fyn struktuur en balans van die perikoop:

\begin{tabular}{|c|c|c|}
\hline God se seëning & Motivering & Tydsbepaling \\
\hline Uitverkiesing & $\begin{array}{l}\text { "na die welbehae van sy } \\
\text { wil" (vers 5) }\end{array}$ & $\begin{array}{l}\text { "voor die grondlegging } \\
\text { van die wêreld" (vers 4) }\end{array}$ \\
\hline Verlossing & $\begin{array}{l}\text { "na die rykdom van sy } \\
\text { genade ..." (vers } 7 \text { ) } \\
\text { "na sy welbehae } \quad . . " \\
\text { (vers 9) }\end{array}$ & $\begin{array}{l}\text { "Om die volheid van die } \\
\text { tye te reël" (vers 10) }\end{array}$ \\
\hline Erflating & $\begin{array}{l}\text { "ooreenkomstig die } \\
\text { voorneme van Hom wat } \\
\text { alles werk volgens die } \\
\text { raad van sy wil" (vers } \\
\text { 11) }\end{array}$ & $\begin{array}{l}\text { "nadat ons vantevore } \\
\text { daartoe verordineer is" } \\
\text { (vers 11) }\end{array}$ \\
\hline Verseëling & $\begin{array}{l}\text { "... die Heilige Gees wat } \\
\text { die onderpand is van } \\
\text { ons erfdeel" (vers } 14 \text { - } \\
\text { versekering) }\end{array}$ & $\begin{array}{l}\text { "om sy eiendom te } \\
\text { verlos" (vers } 14 \text { - toe- } \\
\text { komsbepaling) }\end{array}$ \\
\hline
\end{tabular}

(Mouton, 1987:98) 
Uit die struktuur blyk dit dus duidelik dat God die mens se totale verlossing uit genade en "na sy welbehae" doelgerig beplan het, en op geordende wyse tot uitvoer bring. Tydsgewys sluit dit die oneindige periode in van "voor die grondlegging van die wêreld" tot op die dag wanneer Hy sy eiendom volkome sal verlos. Al die seëninge word soos 'n ketting met die skakels "in Christus", "in Hom", en "in Wie" saamgesnoer. Die gerigtheid van die perikoop, dit wil sê die skrywer se doelbewuste poging om (deur middle van sinjale) reeds vanuit die selektering en ordening van sy materiaal die hoorders se gedagtes in 'n bepaalde rigting te stuur, kom baie duidelik uit die sintaktiese ontleding na vore. Die skrywer wou naamlik sy lesers se gedagtes reg van die begin af op Christus fokus, en op dit wat God in en deur Hom gedoen het (Mouton, 1987:89). Deur die meestersimbole van uitverkiesing, aanneming as kinders, verlossing, bekendmaking van die verborgenheid, ontvangs van 'n erfdeel en verseëling direk aan Christus te koppel, versterk die skrywer nie alleen hulle geloof in Christus nie, maar wys hy ook op die diepste sin van hulle bestaan. In die finale instansie dien die perikoop as 'n aansporing vir die gelowiges met die doel om hulle te oorreed om "tot lof van God se heerlikheid" te wees. Die driedubbele herhaling van die doel van God se seëninge en die strategiese inleidingswoorde dra daartoe by (Mouton, 1987:99).

Samevattend is die strukturele opbou van Efesiërs 1:3-14 gerig op die lofprysing van God vir dit wat Hy in Christus gedoen het. Deur die entoesiastiese trant waarop Paulus God se ingrypende genadewerk stuk vir stuk laat ontvou, asook deur die strategiese plasing van die perikoop as prelude tot sy geskrif, openbaar die skrywer by voorbaat sy uiteindelike bedoeling met die brief (Mouton, 1987:99). Hy wil sy lesers besiel tot ' $n$ inniger kennis en 'n diepe belewing van aanbidding en lofprysing teenoor die God, wat hulle as Vader in Christus uitverkies en verlos het (Bhae, 2000:42). Hierdie simmetriese struktuur van die liturgiese elemente van lofprysing, gebed en belydenis toon die besondere liturgiese dimensie van die Efesiërbrief. Wat Paulus in hierdie brief skryf, het daarom direkte betekenis vir die liturgie van die kerk (Viljoen, 1990:131). Roberts (1984:119) stel dit so:

Daar het met Paulus en sy medestanders waarskynlik die volgende gebeur, soos ons kan aflei uit die brief: 'n erediens het plaasgevind waartydens in 'n berakah God geprys is vir die redding in Christus, veral die redding van nuwe Christene uit die heidendom. Hieruit is die ontstaan van die brief aan die Efesiërs te verklaar: 'n behoefte om die nuwe Christene te laat deel in die lofprysing oor hulle redding. 
Basisteoretiese elemente vir lofliedere wat moontlik uit die struktuur van Efesiërs 1:3-14 na vore kan kom:

- Lofliedere kan gestruktureer word met die berakah-gebedsvorm as riglyn, want daarin kom die lofroep, die redes vir lofprysing, die belydenis (wat dalk in die gedrang was), voorbidding en weer ' $n$ lofprysing aan die orde. Wanneer lof die aanbidding omarm (soos in Ef. 1:3 en Ef. 3:20, 21) kan die loflied tot 'n klimaks gelei word.

- Die lofroep ('n oproep: "Loof God!") as unieke doksologiese formule kan 'n loflied inlei, want dit druk matelose verwondering vir God uit, spesifiek vir wat $\mathrm{Hy}$ in Christus gedoen het.

- Die herhalende kenmerke in die struktuur van hierdie loflied ("in Christus", "volgens die wil van God", "tot verheerliking van God" en die hoë frekwensie van bepaalde voorsetsels) gee riglyne vir die skep en beoordeling van lofliedere ten opsigte van chronologiese ontwikkeling en trinitariese inhoud.

- God se handelinge (uitverkiesing, verlossing, erflating, verseëling), sy metode (in en deur Christus), sy motivering (volgens sy wil), sy aanduiding van tydsbepalings (voor die grondlegging van die wêreld, in die volheid van die tye en sy toekomsvisie), asook sy doel (tot lof van sy heerlikheid) is almal elemente wat lofliedere kan verryk.

\section{Lofliedere - basisteoretiese elemente uit die inhoud van Efesiërs 1:3-14}

Die inhoud van Efesiërs 1:3-14 word vervolgens nagegaan met die doel om basisteoretiese elemente vir die skep en evaluering van lofliedere te probeer vasstel. Daarom word hier nie 'n omvattende eksegetiese studie van hierdie perikoop aangebied nie. Ten spyte van 'n hoogstaande kultuur en geleerdheid, was die stad Efese vasgevang in die greep van bygeloof, towery, besweringe en besetenheid. Die mense is op omslagtige wyse (teen betaling) sogenaamd van hierdie besetenheid bevry. Die evangelie van verlossing moes daarom vir hierdie mense 'n besondere vrymaking gewees het. Die gelowiges kon oor hierdie vrymaking met lofprysing en belydenis in die lied van Efesiërs 1:3-14 sing (Viljoen, 1990:80). Hierdie himne is dus gebore uit die stryd teen en oorwinning oor valse leer en die verwarring en pyn wat die valse leer by mense gebring het. 


\subsection{Lof aan die Drie-enige God}

Dit gaan in hierdie verse om die lofprysing van God Drie-enig. Hy is die Beplanner van die verlossing wat deur Christus tot stand gebring is en die Vader van sy kinders wat sy verbondsvolk en huisgesin uitmaak. Hy is die Verlosser wat die Heerser oor die kosmos sal wees. Hy is die eskatologiese geskenk van God aan sy volk, die Heilige Gees, wat begelei na verlossing en geestelike gawes aan sy volk gee. Wanneer Paulus oproep: Prys die Here! prys hy Hom deur die reddingsdade op te

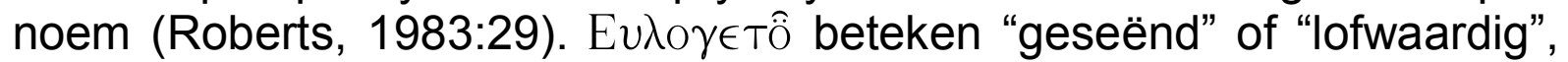
want God het gehandel (dade) in die verre verlede, voor die grondlegging van die wêreld en Hy tree op in die geskiedenis. Deur die geloof word sy dade raakgesien en wie daardeur oorstelp word, kan nie anders as om aan God lof toe te bring nie (Floor, 1995:46). Die perikoop is soos 'n sneeubal wat al groter en groter in sy lof aan God uitswel en in volume toeneem (Stott, 1994:32).

Verwysings na Christus is prominent in hierdie lofprysing. Alhoewel die grammatiese onderwerp verander ("God" in Ef. 1:3-6; "ons" in Ef. 1:7-12 en "julle" in Ef. 1:13-14), bly Christus die semantiese onderwerp. Hy is die Middelaar deur Wie al die seëninge van God die mens toekom (Viljoen, 1990:165). Die frase "in Christus" of "in Hom" kom elf keer in hierdie gedeelte voor. "In Christus" het God ons geseën en uitverkies (verse 3-4); "in die Geliefde" het Hy ons met sy genade oorweldig sodat ons "in Hom" verlossing en vergewing het (verse 6-7). "In Hom" het die eerste Joodse gelowiges God se volk geword (verse 11-12) en "in Hom" is die gelowiges uit die heidene verseël tot God se eiendom (verse 1314). "In Christus" voer God sy plan deur om alle dinge "in Hom", of onder sy Hoofskap, te verenig (verse 9-10; Stott, 1994:34). Om "in Christus te wees" is die sentrale tema van hierdie hele doksologie (Couch, 1988: 217). Elke seëning van die Heilige Gees is aan ons gegee deur die Vader as ons in die Seun is en God se geestelike seëninge is seëninge wat deur die werking van die Heilige Gees ontvang word en die stempel van die Heilige Gees dra (Floor, 1995:49).

\subsection{Lof aan God die Vader}

Hierdie lofwaardige God word beskryf as "Vader van ons Here Jesus Christus". In Efesiërs 1:3-14 tree die wese van God se vaderskap by uitstek na vore as 'n betrokkenheid van genadige en liefdevolle ontferming oor die mens. Dit kom daarin tot uitdrukking dat Hy die mens (wat andersins geen status of toekoms sou hê nie) uitverkies het om sy kind te wees, verlos het deur die bloed van sy Seun en 'n ewige erflating deur die Heilige Gees waarborg (Mouton, 1987:129). God die Vader is die bron en oorsprong van elke seëning wat ons geniet. Sy inisiatief word 
op aangrypende wyse geillustreer deurdat Hy die subjek is van byna elke hoofwerkwoord in hierdie verse (Stott, 1994:33).

Soos hulle in Christus 'n plek in die hemel ontvang het (Ef. 2:6, was hulle ook met die pre-eksistente Christus verenig en so in Hom deur God verkies. Paulus trek hier die gemeente se inbegrepe wees in Christus deur tot in die pre-eksistensie. Soos die gemeente se lewe verborge is in God met die verhoogde Christus (vgl. Kol. 3:3), so ook die verkiesing van die gelowiges voor die grondlegging van die wêreld (Ridderbos, 1966:387). Die perikoop sing oor die uitverkiesing en ons moet daarteen waak om dit te sistematiseer en rigied te bespreek, want in die lofprysende gebed word God as die verkiesende God geprys (Stott, 1994:36). Christus is die middelpunt of die spil waarom die verkiesing van God draai. Jesus sê self dat die uitverkorenes deur die Vader aan Hom gegee is (Joh. 17:2). Omdat die verkiesing voor die grondlegging van die wêreld plaasgevind het, kan niemand by God aanspraak maak op enige verdienste nie. God se doel met die verkiesing is kenbaar, naamlik dat ons hier op aarde reeds heilig en onberispelik in sy teenwoordigheid sal lewe. Die verkiesing moet dus in die lewe van die gelowige sigbaar word (Floor, 1995:51).

Die klem in God se verkiesing is op sy genade, sy liefde, sy wil en sy doel. Verkiesing lei tot aanneming tot kinders. Om heilig en onberispelik voor God te wees beteken om bewustelik in die teenwoordigheid van God te leef - 'n bestaanswyse wat dit 'n onbeskryflike voorreg en 'n voortdurende uitdaging maak om Hom te verheerlik (Stott, 1994:39). Paulus sing van die uitverkiesing in die kader van die liefde en wie oor die uitverkiesing praat, sing oor die liefde van God (Floor, 1995:52). Wie God se liefde wil verstaan, moet aan die kruis van Jesus dink waar die geliefde Seun van God sterf sodat ons begenadig kan word om as kinders aangeneem te word. Aanneming beteken nie alleen om ' $n$ nuwe Vader te hê nie, maar ook dat die aangenome kind 'n nuwe status het en mag deel in die voorregte wat die Vader bied. Paulus sing daarby "daarom moet ons God prys vir sy groot genade ...", want God wil deur die daad van aanneming sy genade laat skitter, sodat mense dit kan besing (Floor, 1995:53).

\subsection{Lof aan Jesus Christus}

Paulus praat eers oor die verlossing van die mens (vers 7 ) en daarna oor die verlossing van die kosmos (vers 9-10). Die spesifieke woord wat Paulus vir "vergewing" gebruik, dui die omvattende van die verlossing aan, want die woord beteken sowel vergewing as vrylating, bevryding. Die verlossing strek veel verder as die vergewing van sonde en daarmee 
die bevryding uit die mag van die sonde en die dood. Die hele skepping mag deel in die verlossing wat Christus verwerf het (Floor, 1995:54).

God het meer gedoen as om ons in Christus te verkies in die ewigheid (verlede) en om ons as sy kinders aan te neem (hede), maar Hy maak ook die geheimenis van sy wil vir die toekoms aan ons bekend (Stott, 1994:41). Dit gaan in God se plan daarom dat die geskiedenis, die opeenvolging van periodes en gebeurtenisse in die wêreld, uitloop op een groot massale daad van hereniging of herstrukturering: alles word byeengebring onder die mag van Christus (Roberts, 1983:35). God sal alles onder die Hoofskap van Christus verenig. Dit sluit gelowiges wat leef en reeds gesterf het in, ook die engele en alles wat God geskep het. Dit gaan dus oor die kosmiese hernuwing, die hergeboorte van die heelal. Die natuur, die geskiedenis en die lewe van mense en volkere lewer die bewys van disharmonie, maar Christus sal op grond van sy verlossingswerk die harmonie herstel. En die kerk van vandag moet in hierdie wêreld al iets sigbaar maak van God se uiteindelike doel met skepping en mensheid. Op hierdie manier gee Paulus alle lesers die geleentheid om mekaar by Christus terug te vind, sonder onderlinge verwyt en met lof voor God. Calvyn meen dat lidmate wat deel vorm van die liggaam van Christus wat saam oor die Here Jesus sing, op grond van dié daad 'n eenheid in hulle Hoof vind (Hasper, 1955:705).

Waar verse 7-10 bevryding as seëning genoem het, dui verse 11-12 die seëning aan dat God ons sy eiendomsvolk gemaak het. Wie bevry is van die mag van die sonde, wie deel van God se eiendom geword het, vind die sin van sy of haar bestaan daarin om aan hierdie wonderlike God die lof te bring wat Hom toekom (Roberts, 1983:37). God laat alles gebeur volgens sy raadsbesluit (verse $5,9,11$ ). Bouג $\eta$ bring die gedagte sterk na vore dat alles van God afkomstig is: Alles begin by God, maar eindig ook by God, want die groot doel is die lof van sy heerlikheid. In hierdie lewe is die verkiesing en voorbeskikking van God (sy wil) gerig op 'n heilige lewe en op die lofprysing van sy Naam (verse 6 en 12). Daar is egter 'n onderskeid tussen vers 6 en 12, want in laasgenoemde vers gaan dit om die gelowiges wat die aanleiding is om God te verheerlik. Die bestaan van 'n uitverkore mensheid in die heelal is ' $n$ kunswerk van God wat besing moet word (Floor, 1995:63). Paulus spoor Jode en heidene aan om in eensgesindheid die lof van die Vader van ons Here Jesus Christus te sing (Malan, 1998:511).

\subsection{Lof aan die Heilige Gees}

Die kerk is God se erfgename en eiendom deur God se wil (vgl. verse 5, $9,11,12)$. Die versekering dat God aktief in ons werk, is deur die Heilige Gees gegee. In verse 13 en 14 word drie kenmerke aan die Heilige Gees 
toegeskryf: belofte, seël en waarborg. Hy is die Gees van belofte omdat God in die Ou Testament Hom al aan die kerk beloof het (Ridderbos, 1966:445). Die Gees is 'n seël omdat God Hom in ons harte plaas om ons te merk as sy eiendom. Die Heilige Gees is God se waarborg om God se volk veilig by hulle finale erfenis te bring (Stott, 1994:47). Wanneer Paulus oor die Heilige Gees in hierdie verse jubel, verloor hy Christus nie uit die oog nie, want Christus en die Gees is innig verbonde en die werk van die Heilige Gees mag nooit van Christus losgemaak word nie (Floor, 1995:65). Paulus beweeg van "ons" (hy en die Joodse gelowiges) na "julle" (die gelowiges uit die heidene) en weer na "ons" erfenis (waarin albei groepe gelykelik deel). Omdat God die "julle" by die "ons" gevoeg het, hulle saam bevry het uit die volke om sy eiendomsvolk, sy besitting te wees, 'n volk wat sy verlossing as hulle erfenis ontvang - daarom moet hulle saam die wonderlike God prys (Roberts, 1983:43).

Wanneer Paulus in vers 13 van verseëling praat, wend hy 'n bekende antieke gebruik metafories aan om God se eienaarskap ten opsigte van sy kinders te bekragtig en die versekering van sy liefde en versorging vir hulle te waarborg (Coetzee, 1984:250; vgl. Anglada, 1987:85-94). Uit die konteks van Efesiërs 1:3-14 blyk dit dat die Heilige Gees God se teken aan die gelowiges is - ' $n$ teken waarmee Hy hulle as sy ware eiendom gemerk het. Ten nouste hiermee verbonde is die beskrywing van die Heilige Gees as die "onderpand" van ons erfdeel. Met die keuse van die begrip $\alpha \rho \rho \alpha \beta \omega \nu$ wil Paulus nogeens die absolute sekerheid en betroubaarheid van God se heilswerk in Christus kommunikeer (Mouton, 1987:139). Paulus verbind die verseëling met die Heilige Gees met die prediking van die evangelie en die tot geloof kom. Die evangelie word verseël met 'n tweërlei lof: dit is die woord van die waarheid en die woord van verlossing, want die woord het die waarheid tot inhoud en is bedoel om verlossing te bewerk. Hierdie verseëling staan nie los van die geloof nie, maar is onlosmaaklik daaraan verbonde (Floor, 1995:66). Drie keer word gesing oor die wil van God en drie keer besing Paulus die heerlikheid van God. Alles wat gelowiges het, kom van God en gaan weer terug tot Hom, want dit begin met sy wil en eindig met sy verheerliking (Stott, 1994:49). Om die grootheid van God se genade te prys moet gelowiges self God in woord en lewe verheerlik, maar hulle moet ook toesien dat ander dit doen.

Die verheerliking van God staan in skrille kontras met mensgesentreerdheid en selfgesentreerdheid. Selfs in 'n lofprysing kan die lied neig na 'n ek-lied waarin God nie verheerlik word nie. Die nuwe volk van God het nuwe waardes en nuwe ideale, want gelowiges is God se eiendom wat leef volgens sy wil en tot sy verheerliking. In die praktyk van die lewe en as versamelde gemeenskap in die erediens moet die 
kerk steeds die lof van God besing en sy heerlikheid uitstraal deur versoening te bring in 'n verskeurde wêreld. Die hoofklem van die perikoop lê op die feit dat God lofwaardig is omdat Hy al hierdie dinge tot stand gebring het en dat Hy juis om hierdie rede deur die kerk as sy bevryde volk onophoudelik geprys moet word. Die kerk is trouens die gemeenskap van hulle wat God prys (Roberts, 1983:44). Efesiërs 1:3-14 is genoem "die doksologie op die goddelike plan van verlossing" omdat dit 'n samevatting is van die dogma van God se verlossing vir die mens en die kosmiese eenheid onder die Hoof Christus, gewaarborg deur God en verseël met die Heilige Gees (Couch, 1988:215).

Basisteoretiese elemente vir lofliedere wat moontlik uit die inhoud van Efesiërs 1:3-14 na vore kan kom:

- Die loflied behoort rekening te hou met die stryd van gelowiges in bepaalde omstandighede (vgl. Ef. 1:3-14 se ontstaan te midde van stryd teen bygeloof, towery, besweringe en besetenheid). Die loflied kan daarom enersyds die dwaling bestry en andersyds ' $n$ antwoord wees op die oorwinning oor dwaling of vervolging.

- Die loflied behoort die Drie-enige God te besing en die dade van God in die verlede, hede en toekoms in 'n lied, wat in krag en volume toeneem, te prys. Dit behoort die geestelike seëninge van God in Christus deur die Heilige Gees aan die orde te stel.

- Gelowiges benodig meer lofliedere oor die wonder van die uitverkiesing deur God. In lofprysings oor sy uitverkiesing moet die klem val op die verkiesing in Christus, van voor die grondlegging van die wêreld af - 'n uitverkiesing uit louter liefde en wat lei tot die aanneming as sy kinders.

- Lofliedere, in hierdie tye van kerklike verskeurdheid, behoort die wonder van God se plan om gelowiges (en die kosmos) onder Christus as Hoof te verenig, te besing. Dit is veral nodig om die wonder van die eenheid van die kerk, as voorafskaduwing van die komende eenheid, te verwoord. Wanneer gelowiges oor alle grense heen hulle eenheid besing, kan hulle hulle eenheid weer vind in hulle Hoof, Christus.

- In reaksie teen geesdrywery word die Persoon en werk van die Heilige Gees dalk in lofliedere onderbeklemtoon. Hierdie lied (Ef. 1:3-14) gee riglyne om die Gees se verseëling en waarborg dat gelowiges God se eiendom en erfgename is, te besing. Die loflied se visie op die heerlike toekoms wat deur die Gees aan gelowiges verseker word, is ' $n$ element wat in vandag se lofliedere aan die orde behoort te kom. 
- Die bestaan van 'n uitverkore mensheid in die heelal is ' $n$ kunswerk van God wat besing moet word.

- Lofliedere op die evangelie as waarheid en instrument om verlossing te proklameer is in tye waarin die gesag van die Woord in gedrang kom, uiters noodsaaklik.

\section{Lofliedere - basisteoretiese elemente uit die verhouding dogma-doksa}

Uit die struktuur en inhoud van Efesiërs 1:3-14 blyk hoe belangrik die verhouding tussen dogma en doksa is. Daarom behoort hierdie verhouding kortliks bespreek te word. Teen die agtergrond van die heidense pessimisme in Efese en Klein-Asië en die Oosterse astrologie het die sogenaamde "liedere aan Christus" op die voorgrond getree (Barkhuizen, 1985:3). Bogenoemde liedere, vanuit gnostiese denke, het ontken dat Christus die enigste Middelaar tussen God en mens is en hulle het die gesag en heerskappy van die sterre-gode gehandhaaf. Liedere in die Nuwe Testament het veral die gnostiese idees bestry en het Christus as Here, Middelaar en Hoof positief besing (Martin, 1983:134; Vos \& Pieterse, 1997:57). Hierdie belydenis aangaande Christus (onder andere ook in Ef. 1:3-14) rus op openbaring. Deur die kerk se himnes in die Nuwe Testament te kontrasteer met die heidense gnostiese liedere word die openbaring se grondliggende belang in die ontstaan van die liturgiese lied op 'n besondere wyse beklemtoon. Die himne sing egter nie net van die openbaringsfeite nie, maar laat dit openbaring-in-aksie word. In die aktuele situasie "beweeg" die openbaring dus van die historiese, objektiewe feite wat "staan", na 'n lewende proklamering van die openbaringsgebeure in Christus. So weerlê die lied lewendig, prakties en aktueel die dwaling en sing dit as geloofsrespons die Christusopenbaring in die omgewing en leefwêreld van die jong kerk (Bingle, 2000:51). Die liedere is soos spieëls wat die geloof van die jong kerk reflekteer. Die lied neem die doksa van God waar en gee erkennend uiting daaraan, want op God se doen en dade volg lied en lof in belydenis, maar nie as belydenisskrif nie; dit is belydende verheerliking (Bingle, 2000:52).

Omdat die himnes en credo's by mekaar aangesluit het, het die ontwikkeling van die liedere ook tot die ontwikkeling van die dogma van die kerk bygedra. Teenoor die Ariane wat die mense deur hulle ligte liedere afvallig gemaak het, het Ambrosius die gemeente waardige liedere laat sing om die regsinnige waarhede by hulle in te skerp. Ambrosius het gemeentes selfs dae en nagte aaneen laat sing om die suiwere waarheid sodoende by hulle te laat ingang vind. Augustinus skryf in die Confessiones (Belydenisse) dat wanneer klanke in sy ore invloei, die 
waarheid dan in sy hart invloei (9,6; Viljoen, 1990:11). Die lied is 'n duidelike missionêre aksie waardeur ongelowiges tot gesamentlike belydenis van die geloof en lofbetuiging aangespoor word (Viljoen, 1990:133). Die woorde van die himne vul die gedagtes van die gelowiges in tye van krisis en dankbaarheid en wanneer hulle leiding soek. Himnes begelei die gelowiges in hulle daaglikse beslissings en in hulle kontak met die valse leer. In die Pauliniese briewe word himnes byvoorbeeld ingesluit om dié doel te bereik (Malan, 1998:522).

Bingle $(2000: 58,59)$ toon die verhouding openbaring, dogmavorming en doksa-uiting op 'n oortuigende wyse aan: die verhouding van die openbaring tot dogmavorming is kousaal van aard, want die openbaring is verantwoordelik daarvoor dat die dogma in die lied vorm kry. Ook is die openbaring die stimulus vir die inhoud van die belydenis wat liedmatig kristalliseer en veroorsaak dat dit wat in die lied bely word, lewende dogma is. Ook die verhouding openbaring tot doksa is kousaal van aard, want die doksa word nie deur die lieddigter of -sanger geskep of bedink nie, maar deur die openbaring in 'n verheerlikende handeling omskep. Die verhouding tussen die twee "gevolge" (dogmavorming en doksa-uiting) van die openbaring wat in die lied as 'n twee-eenheid gestalte kry, is konvergerend, wisselend en simbioties van aard. Albei loop saam en ewe sterk uit die openbaring (konvergensie), kom saam in 'n himniese handeling waarin die een die ander beïnvloed en stileer (wisselwerking), en die twee uiteindelik nie sonder mekaar bestaan nie (simbiose). Daarom kan Bingle (2000:157) tot die konklusie kom dat liedere waarin die verhouding openbaring-dogmavorming-doksa-uiting suiwer is, inderdaad die sangers 'n nuwe geloofswerklikheid laat betree.

\section{Moontlike basisteoretiese elemente uit die verhouding dogma en doksa:}

- Die sing van die openbaring (berymde Nuwe-Testamentiese lofliedere) kan lei tot 'n herwaardering en selfs 'n herlewing van die kerk se belydenis en tot die vorming van lofliedere wat Skrifgetrou, maar nie noodwendig berymings of omdigtings van bepaalde Skrifgedeeltes is nie.

- Die skep van die dogmatiese lied (in ooreenstemming met Skrif en belydenis) kan 'n kragtige middel wees tot die inskerping van die belydenis en tot die besef dat dogmavorming en doksa-uiting wisselend en simbioties van aard is. 


\section{Kort evaluering oor die hedendaagse praise and worship-liedere}

Praise-musiek se oorsprong lê in die tydperk tussen 1960 en 1970 toe die Jesus People movements van kore en veral Afro-Amerikaanse musiek gebruik gemaak het. Hierdie musiek, met sy populêre melodieë en afgewaterde lirieke, het groot inslag gevind en het vir herlewing en vernuwing in baie kerke gesorg. Die invloed daarvan sal nog lank in sekere kerke bly, maar populêre musiek uit 'n populêre kultuur loop altyd die gevaar dat dit nie populêr sal bly nie (Bradley, 2000:44). Daar is in hierdie populêre musikale genres (die praise and worship) 'n groot verskeidenheid high-tech-produkte om sangleiers te ondersteun en werkswinkels hieroor word dwarsdeur die wêreld aangebied (Hamilton, 1999:30). Baie geloofsgroepe verabsoluteer hierdie musiek as die enigste aanbiddingsvorm: Praise and worship in sy ekstreme vorm oorheers die samekoms in so 'n mate dat baie mense dink dat praise songs die enigste "valid form of worship" is (Bierly, 1997:39).

Is praise and worship-musiek werklik lofliedere? Daar is sekere populêre misverstande oor wat lofprysing is. Die eerste is dat lofprysing 'n soort tegniek is om mense mee te sleur, te inspireer, mee te voer, entoesiasties, betrokke en opgewek te kry. Sulke lofliedere moet mense in die regte stemming kry en 'n aangename gees skep en buitestanders lok, omdat hulle lofprysingsessies so genoeglik en meesleurend vind. Die tegnieke van die samelewing word nageboots en daarom word gepoog om dieselfde stemming skep as by disko's en konserte sodat die mense moet kom en dit geniet. Maar in die Bybelse sin is egte lofprysing die teenoorgestelde hiervan, want lofliedere was die reaksie van gelowiges op die evangelie en tot God gerig. Dit was die blye, dankbare, verwonderde, vreugdevolle reaksie op die Persoon en dade van die Drieenige God (Smit, 1997:390). Die praise and worship-lied is in die oorgrote meerderheid van gevalle 'n "ek-lied". Hedonisme, spectatorism en sentimentaliteit is kenmerkend van hierdie "ek"-lied in sy kontemporêre vergestalting (Bingle, 2000:128). Die ervaring, eerder as God, word aanbid: praising praise en worshipping worship (Strydom, 1995:41). Sang begin sodoende (op 'n subtiele wyse) funksioneer as 'n godsdienstige vermaaklikheidsmedium wat aanpas by die sekulêre "superster"verbruikersmentaliteit (Strydom, 1997:147; vgl. De Klerk, 2000:452-457).

Konflik oor liturgie in die algemeen en musiek in die besonder het in alle kerkgemeenskappe ontstaan. Soms word dienste op verskillende tye vir verskillende smake gehou (Hamilton, 1999:30), maar dit is nie produktief om by verskillende geleenthede verskillende soorte musiek te laat sing nie, want sodoende kry die jeug dan geen blootstelling aan die skoner vorme van musiek en aan die uitdrukking van pyn in die lied nie 
(Kloppers, 1997:184). Nuwe musikale vorme hoef egter nie in alle gevalle negatief beoordeel te word nie. Terwyl die kerk die roeping het om evangeliserend uit te reik, moet hy ernstig worstel met wyses van aanbidding en musikale vorme in 'n poging om nie-gelowiges vir Christus te bereik. Terwyl die kerk sy liedere wat uit sy eie geskiedenis gebore is, met passie en oorgawe moet sing, moet die kerk ook nie bang wees om verandering versigtig, met integriteit en pastoraal aan te pak nie (Brink, 1997:64).

Daar moet genoeg himnes wees om God se heerlikheid te besing, maar ook genoeg om die sondaar se stryd met God te vertolk. Eensydige klem lei tot eensydige ervaring en uitdrukking van geloof wat die gelowige ook verkeerde leerstellige standpunte kan laat inneem.

A one-sided emphasis, say, on the celebrative aspect, day after day, also brings about a diminished concept of faith, where it is assumed that faith means feeling good, being happy, succesful, strong in trust. But what about the other sides of faith? (Kloppers, 1997:179).

Lofprysing is nie bloot 'n opwekking of 'n uiting om goed te voel nie, want egte lof tot God is gebore in pyn en 'n hulpgeroep uit die dieptes. Die jubeling is gebore uit aanvegting, vrees, twyfel, teenkanting en selfs vervolging. Omdat die lofprysing uit die dieptes gebore word, is dit altyd liedere van hoop. Egte Christelike lofprysing word opgeroep wanneer die genadige beloftes van die troue en lewende God met verwondering en dankbaarheid gehoor en aangeneem word, te midde van die dieptes van ons alledaagse bestaan (Smit, 1997:393).

\section{Samevattende basisteoretiese elemente uit die ondersoek}

- In die skep en evaluering van lofliedere is 'n goed beplande struktuur, deur byvoorbeeld die gebruikmaking van die refrein en herhaling van die belangrikste temas, noodsaaklik. Verwondering vir God kan in die struktuur tot uitdrukking kom deur die gebruikmaking van lofroepe, beweging na 'n klimaks in die lied en die hantering van elemente soos God se handeling in verbinding met sy metode, motivering en doel van die handelinge.

- Die loflied behoort die skoonheid van die Drie-enige God en sy groot dade te besing. Die kerk het behoefte aan meer Skrifgetroue lofliedere wat voortspruit uit verwondering oor die dade van die Vader, Jesus Christus en die Heilige Gees. Wat onder andere in die skep en evaluering van liedere aan die orde moet kom, is God se uitverkiesing in Christus, God se verlossing deur Christus, God se plan om alles onder die Hoof Christus te verenig, God se 
versekering deur die Heilige Gees dat $\mathrm{Hy}$ die gelowiges veilig by hulle ewige bestemming sal bring. Die loflied behoort sy oorsprong te vind in die openbaring en moet beslag kry in wisselwerking met die dogma, sonder om noodwendig 'n beryming van die Skrif of die dogma te wees.

- Die loflied het steeds 'n belangrike rol in die formasie van die kerk en in die opbou van die gemeente in die bewaring en aktualisering van sy belydenis. Die loflied het die funksie om die belydenis op unieke wyse in die hart van twyfelaars en ongelowiges in te dra. Die loflied behoort uit die stryd en pyn van die kerk gebore te word en behoort nie voort te kom uit sentimentele en opswepende motiewe nie.

\section{Bibliografie}

ANGLADA, P.R.B. 1987. The sealing with the spirit in Ephesians 1:13. An exegetical

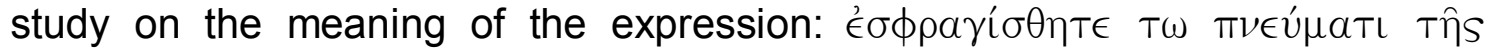

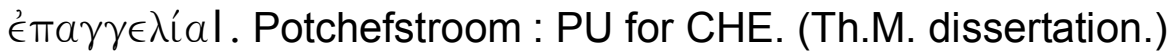

BARKHUIZEN, J.H. 1985. Carmen Christianum. 'n Inleiding tot die Grieks-Christelike Himnografie van die eerste ses eeue. Pretoria : N-G Kerk.

BARKHUIZEN, J.H. 1989. Inleiding. (In Barkhuizen, J.H., red. Hymni Christiani. Pretoria : Hervormde Teologiese Studies. p. 1-16.) (HTS Supplementum 1.)

BARKHUIZEN, J.H. 1990. The strophic structure of the eulogy of Ephesians 1:3-14. Hervormde Teologiese Studies, 46(3):390-413.

BHAE, J-Y. 2000. The subject of the letter to the Ephesians: a thought-mapping approach. Potchefstroom : PU for CHE. (Ph.D- thesis.)

BIERLY, S. 1997. Sparring over worship: 5 points to make when your congregation dukes it over musical styles. Leadership, 18:36-39.

BINGLE, J.P. 2000. Die verhouding tussen openbaring, dogmavorming en doksauiting in die liturgiese lied. Potchefstroom : PU vir CHO. (Th.M.-verhandeling.)

BRADLEY, C-R. 2000. Changes in music. Southwestern Journal of Theology, 42(3):38-55.

BRINK, E.R., ed. 1997. Authentic worship in a changing culture. Study Report CRC. Grand Rapids : CRC Publications.

COETZEE, J.C. 1984. Die Heilige Gees in die prediking van Paulus. (In Du Toit, A.B., red. Handleiding by die Nuwe Testament. V. Pretoria : N.G. Kerkboekhandel. p. 234-255.)

COPES, D.B. 1996. Interpreting Ephesians 1-3: God's people in the mystery of his will. Southwestern Journal of Theology, 39(1):20-31.

COUCH, B.M. 1988. Blessed be he who has blesses: Ephesians 1:3-14. International Review of Mission, 77(306):213-220.

DE KLERK, B.J. 1988. Koninkryk, Gees en Woord in die gebed van Efesiërs 3:14-21. (In Coetzee, J.C., red. Koninkryk, Gees en Woord: Huldigingsbundel aangebied aan prof. dr. Lamberts Floor. Pretoria : N-G Kerkboekhandel. p. 38-54.)

DE KLERK, B.J. 2000. Liturgiese identiteitsvorming as antwoord op die invloed van die verbruikerskultuur. In die Skriflig, 34(4):451-468.

FLOOR, L. 1995. Efeziërs. Eén in Christus. Commentaar op het Nieuwe Testament. Kampen : Kok. 
HAMILTON, M.S. 1999. The triumph of the praise songs. How guitars beat out the organ in the worship wars. Christianity Today, 42:28-35.

HASPER, H. 1955. Calvijns beginsel voor de zang in de eredienst, 1. 's-Gravenhage : Nijhoff.

KLOPPERS, E. 1997. Liturgical music: Worship or war? Hervormde Teologiese Studies, 53(1 \& 2):172-184. (Herdruk uit Dialog, 1995 nommer 34.)

MALAN, F.S. 1998. Church singing according to the Pauline Epistles. Neotestamentica, 32(2):509-524.

MARTIN, R.P. 1983. New Testament hymns: Background and development. Expository Times, 94/95:132-136.

MOUTON, A.E.J. 1987. 'n Eksegeties-hermeneutiese verkenning van die $\epsilon \nu$ X $\rho\llcorner\sigma \tau \hat{A}-$ kernbelydenis by Paulus na aanleiding van Efesiërs 1:3-14. Port Elizabeth : Universiteit van Port Elizabeth. (M.A.-verhandeling.)

RIDDERBOS, H. 1966. Paulus. Ontwerp van zijn theologie. Kampen : Kok.

ROBERTS, J.H. 1983. Die brief aan die Efesiërs. Kaapstad : N.G. Kerk-Uitgewers.

ROBERTS, J.H. 1984. Die gevangeskapsbriewe. (In Du Toit, A.B., red. Handleiding by die Nuwe Testament V. Pretoria : N.G. Kerkboekhandel. p. 114-157.)

SMIT, D. 1997. Oor lofprysing - en die Verenigende Gereformeerde Kerk in SuiderAfrika. Nederduitse Gereformeerde Teologiese Tydskrif, 38(4):389-396.

STOTT, J.R.W. 1994. The message of Ephesians. God's new society. Leicester : Inter-Varsity.

STRYDOM, W.M.L. 1995. "Gospel" deug darem nie as kerkliedere nie. Vir die Musiekleier, 22:40-41.

STRYDOM, W.M.L. 1997. Liturgiese sang op die kruispad tussen tradisie en vernuwing. Acta Theologica, 1997(2):143-156.

VILJOEN, F.P. 1990. Die betekenis van "psalmois, humnois" en "odais pneumatikais" in Kolossense 3:16 en Efesiërs 5:19. Potchefstroom : PU vir CHO. (Th. D.proefskrif.)

VOS, C.J.A. \& PIETERSE, H.J.C. 1997. Hoe lieflik is u woning. Studies in Praktiese Teologie. Pretoria : RGN-Uitgewery.

WAINRIGHT, G. 1980. Doxology: The praise of God in worship, doctrine and life. London : Epworth.

\section{Kernbegrippe:}

basisteoretiese elemente

Efesiërs 1

lofprysing

praise and worship-beweging

\section{Key concepts:}

Basis-theoretical elements

Ephesians 1

praise and worship movement

songs of praise 